Proc. Estonian Acad. Sci. Eng., 2005, 11, 3, 207-214

\title{
Investigation of the domestic hot water consumption in apartment buildings
}

\author{
Alvar Toode and Teet-Andrus Kõiv \\ Department of Environmental Engineering, Tallinn University of Technology, Ehitajate tee 5, \\ 19086 Tallinn, Estonia; takoiv@edu.ttu.ee \\ Received 18 March 2004, in revised form 13 December 2004 \\ Abstract. Domestic hot water consumption profile in five apartment buildings is investigated. \\ Consumption profiles in 1973 and 2003 are compared. Domestic hot and total water consumption \\ data within the last five years are presented. Decrease in domestic hot water consumption is one of \\ the main reasons for decrease in the heat requirements in typical apartment buildings.
}

Key words: domestic hot water, consumption profile.

\section{INTRODUCTION}

For finding out domestic hot water consumption rates and for optimal dimensioning of the hot water heating equipment it is necessary to determine the actual domestic hot water consumption and the consumption profile. Changes in domestic hot water consumption in the past few years has evoked certain interest. The aim of this investigation is to determine the domestic hot water consumption level and the consumption profile in apartment buildings - in the biggest hot water consumption group. Some general data about the use of water in Europe are presented in Eurostat 2003 materials [ $\left.{ }^{1}\right]$, but no respective data on Estonia is available.

One of the interesting aspects in the operation and maintenance of apartment buildings is the domestic hot water consumption rate and its change in recent years. The first investigation of domestic hot water consumption of typical apartment buildings in Tallinn was made in $1973\left[^{2}\right]$. Another heat consumption investigation of the domestic hot water heating in Tallinn apartment buildings was made in $1998\left[^{3}\right]$. The first more extensive analysis of domestic hot water consumption, made by the authors of this paper in 2000, was based on the consumption data of 1999 in 113 buildings [ $\left.{ }^{4}\right]$. 


\section{INVESTIGATED BUILDINGS}

The current investigation considers 22 typical panel residential buildings in the Tallinn Mustamäe District and one 18-apartment building in the centre of the city. All the investigated buildings have modern automatic heating substations and are equipped with contemporary heat meters as well as with hot and cold water meters. Domestic hot water systems in panel residential buildings are equipped with circulation pipes and towel dryers in bathrooms. In most buildings the hot water systems have been renovated. Circulation pipes are balanced except in the 18-apartment building, where hot water circulates only in the main pipe in the basement. There are no towel dryers in that building. All apartments are equipped with two hot water mixers: one in the bathroom and the other in the kitchen. Due to the fact that all the heating substations have been equipped with hot and total water meters, it was possible to analyse the domestic hot water consumption and the consumption profile in investigated buildings.

\section{INVESTIGATION OF THE DOMESTIC HOT WATER CONSUMPTION PROFILE}

The latest investigation of the hot water consumption profile in Tallinn apartment buildings, carried out in $1973\left[^{2}\right]$, involved three typical 90-apartment buildings in the Mustamäe District within 19 weeks. The hourly variation in domestic hot water consumption is indicated with the ratio of the given hourly consumption to average hourly consumption of a week $k_{\mathrm{h}}$, which is calculated as

$$
k_{\mathrm{h}}=\frac{G}{G^{\mathrm{av}}},
$$

where $G$ is the given hourly domestic hot water consumption $\left(\mathrm{m}^{3} / \mathrm{h}\right)$ and $G^{\mathrm{av}}$ is the average hourly domestic hot water consumption of the week.

The ratio $k_{\mathrm{h}}$ for a typical apartment building in November 1973 is presented in Fig. 1 and the hot water consumption data in Table 1.

These consumption rates coincide with the results, obtained by other investigators in the former Soviet Union $\left[^{5-7}\right]$.

To determine changes in the domestic hot water consumption in recent years, the hot water consumption profile was investigated in five apartment buildings in Tallinn in 2003 and 2004. Water meters with impulse output, connected with data loggers, were used for measurements. The measurement period for a building was one week. Hot water consumption rates in litres per day per person for different days of the week in four typical apartment buildings are presented in Table 2 and the weekly variability of domestic hot water consumption of different buildings in Figs. 2 to 5. 


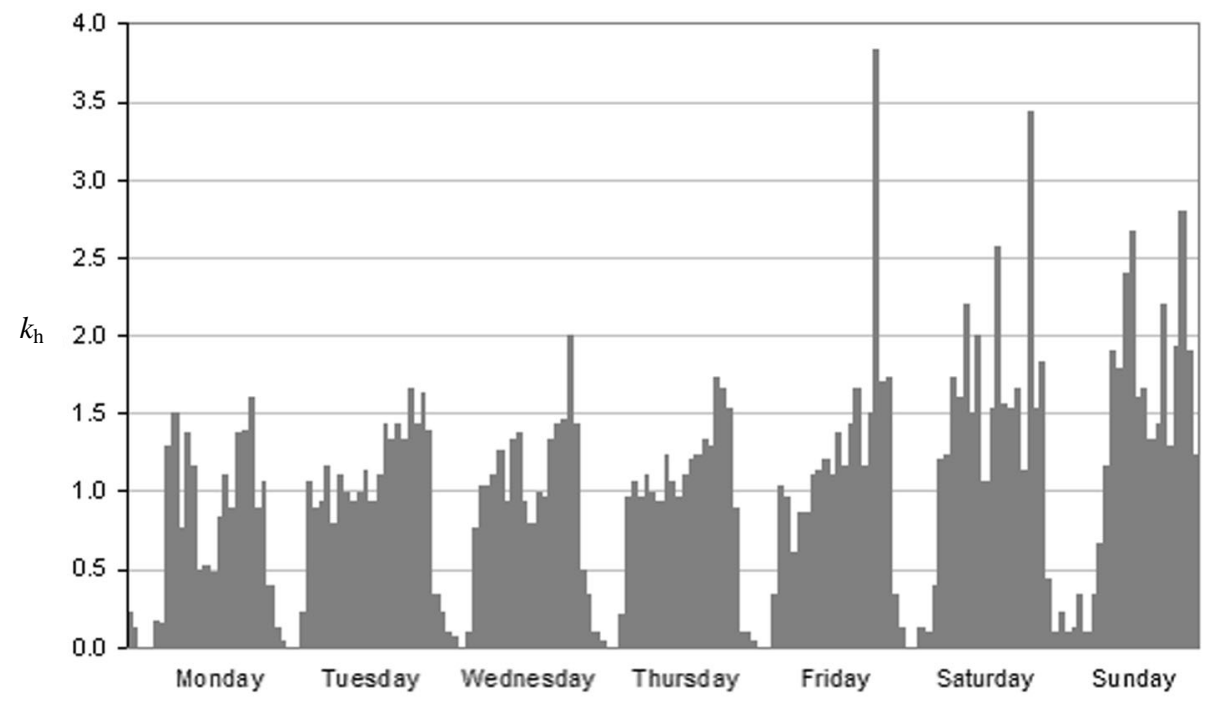

Fig. 1. Ratio of the hourly domestic hot water consumption to the average hourly consumption of a week in a typical apartment building (16, Siili Street, November, 1973).

Table 1. Domestic hot water consumption rates in litres per day per person in the Mustamäe District typical apartment buildings in 1973

\begin{tabular}{l|c|c|c|c|c|c|c|c}
\hline & Mon & Tue & Wed & Thu & Fri & Sat & Sun & Average \\
\hline Average & 83 & 81 & 81 & 80 & 90 & 123 & 125 & 95 \\
Range & $77-98$ & $74-93$ & $68-90$ & $70-88$ & $81-107$ & $112-144$ & $111-150$ & $85-110$
\end{tabular}

Table 2. Domestic hot water consumption rates in $1 / \mathrm{d}$ per person in a Mustamäe District typical apartment buildings in 2003

\begin{tabular}{l|c|c|c|c|c|c|c|c}
\hline $\begin{array}{c}\text { Type of the } \\
\text { building }\end{array}$ & Mon & Tue & Wed & Thu & Fri & Sat & Sun & Average \\
\hline 30-apartment & 41 & 47 & 44 & 44 & 39 & 46 & 54 & 45 \\
60-apartment & 36 & 35 & 34 & 39 & 36 & 45 & 49 & 39 \\
90-apartment & 55 & 57 & 54 & 60 & 50 & 53 & 69 & 57 \\
120-apartment & 34 & 30 & 29 & 36 & 30 & 33 & 36 & 33 \\
\hline Average & 42 & 42 & 40 & 45 & 38 & 44 & 52 & 43 \\
Range & $34-55$ & $30-57$ & $29-54$ & $36-60$ & $30-50$ & $33-53$ & $36-69$ & $33-57$
\end{tabular}

From the data in Tables 1 and 2 we can see that in recent years the domestic hot water consumption on different week days has become more uniform. Comparing the domestic hot water consumption profiles in the seventies and today we can see clear changes, especially on work days. The morning and the evening top consumption is much higher today. On some days the morning top 


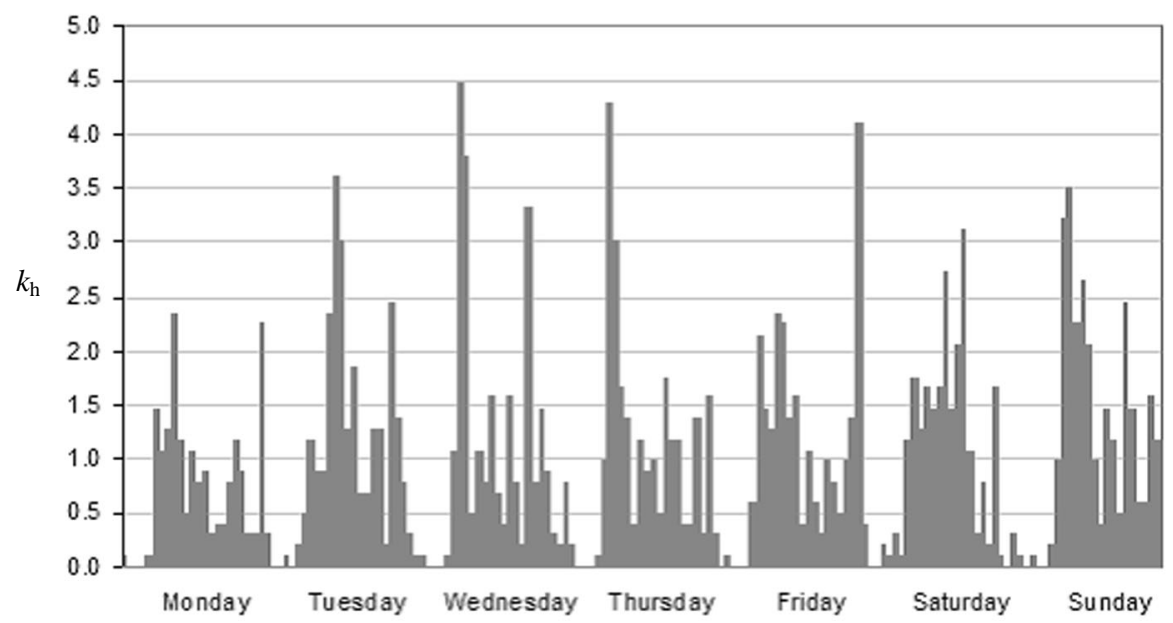

Fig. 2. Ratio of the hourly domestic hot water consumption to the average hourly consumption of a week in an 18-apartment building (February, 2004).

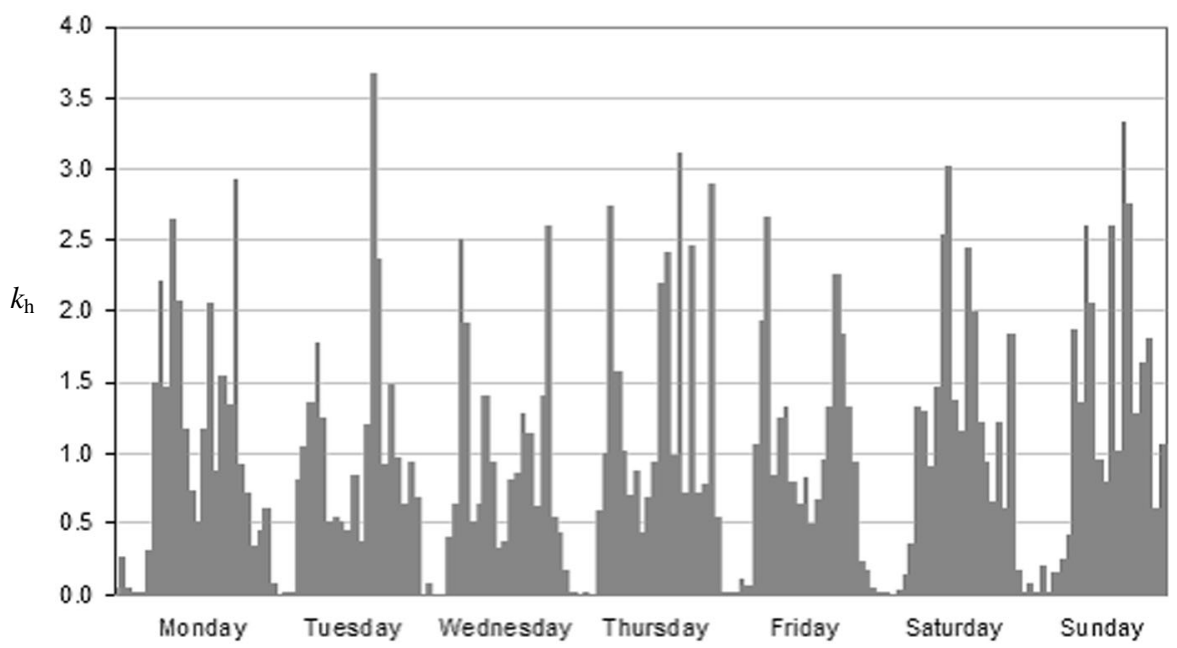

Fig. 3. Ratio of the hourly domestic hot water consumption to the average hourly consumption of a week in a 30-apartment building (November, 2003).

consumption level is higher than the evening one. In the seventies it was vice versa; the rise in the consumption in the mornings was occasional.

According to the measurement results, the peak flow rates were $0.61 / \mathrm{s}$ in a 30 -apartment building and $0.9 \mathrm{l} / \mathrm{s}$ in a 90 -apartment building.

These values are essentially different from design values calculated by EVS standard $\left[{ }^{8}\right]$. 


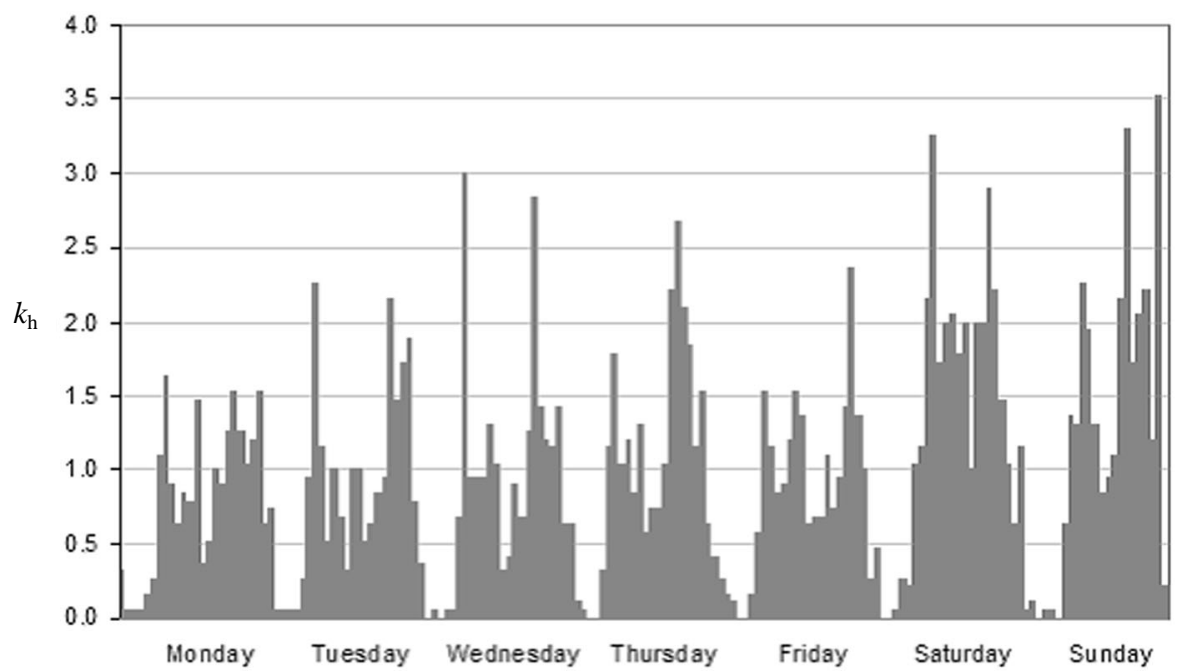

Fig. 4. Ratio of the hourly domestic hot water consumption to the average hourly consumption of a week in a 60-apartment building (December, 2003).

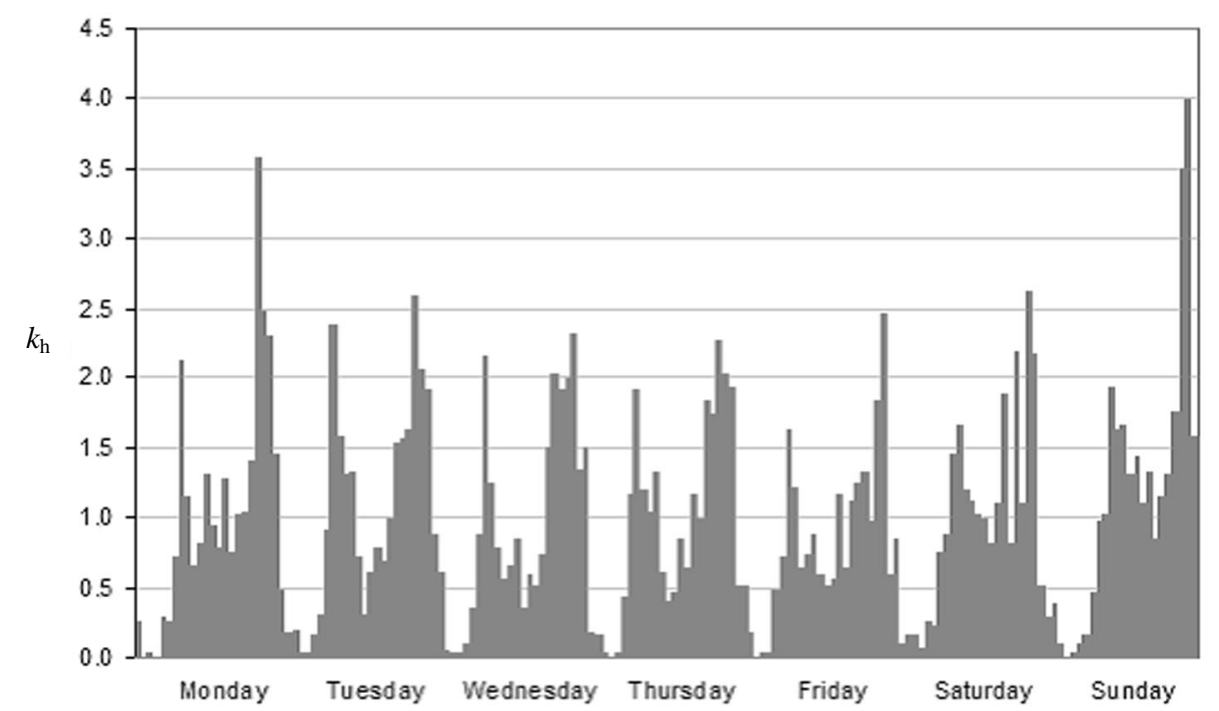

Fig. 5. Ratio of the hourly domestic hot water consumption to the average hourly consumption of a week in a 90-apartment building (November, 2003).

\section{DOMESTIC HOT WATER CONSUMPTION IN APARTMENT BUILDINGS}

Compared with the seventies, in 1999 consumption has decreased approximately twice. Taking into account great changes in the water and heat cost, renovation of domestic hot water systems, water metering in apartments and 
replacement of old taps and showers with modern ones, it is interesting to find out changes in domestic hot water consumption in recent years. The data about domestic hot water consumption in 19 typical apartment buildings in Tallinn (Mustamäe District) from 1999 to 2003 are available. The average domestic hot water consumption data for these years are presented in Fig. 6 . We can see a very clear tendency of decrease in consumption: about $0.2 \mathrm{l} / \mathrm{d}$ per square metre of general apartment area per year. From 59 1/d per person in 1999, the domestic hot water consumption decreased to $461 / \mathrm{d}$ per person in 2003. Table 3 gives average heat consumption data of tap water heating per year in 60-apartment buildings.

Heat consumption of domestic hot water heating $Q_{\mathrm{hw}}$ is calculated in MWh as

$$
Q_{\mathrm{hw}}=\frac{10^{-6}}{3.6} c \rho \sum_{i=1}^{12}\left(q_{i} \Delta t_{i}\right)
$$

where $q_{i}$ is the domestic hot water consumption in respective month $\left(\mathrm{m}^{3}\right), \Delta t_{i}$ is the difference in hot and cold tap water temperatures $\left({ }^{\circ} \mathrm{C}\right), \Delta t_{i}=t_{\mathrm{hw}}-t_{\mathrm{cw} i}\left({ }^{\circ} \mathrm{C}\right)$, $t_{\mathrm{hw}}$ is the hot water temperature $\left(55^{\circ} \mathrm{C}\right), t_{\mathrm{cw} i}$ is the cold water temperature for respective month in cold water supply system, $c$ is the specific heat of water $\left(\mathrm{kJ} /\left(\mathrm{kg}{ }^{\circ} \mathrm{C}\right)\right)$ and $\rho$ is the density of water $\left(\mathrm{kg} / \mathrm{m}^{3}\right)$.

From Table 3 it follows that the decrease in domestic hot water consumption has led to a considerable decrease of heat consumption, 23\% during five years. This is about $6 \%$ of the total heat consumption decrease in investigated apartment buildings.

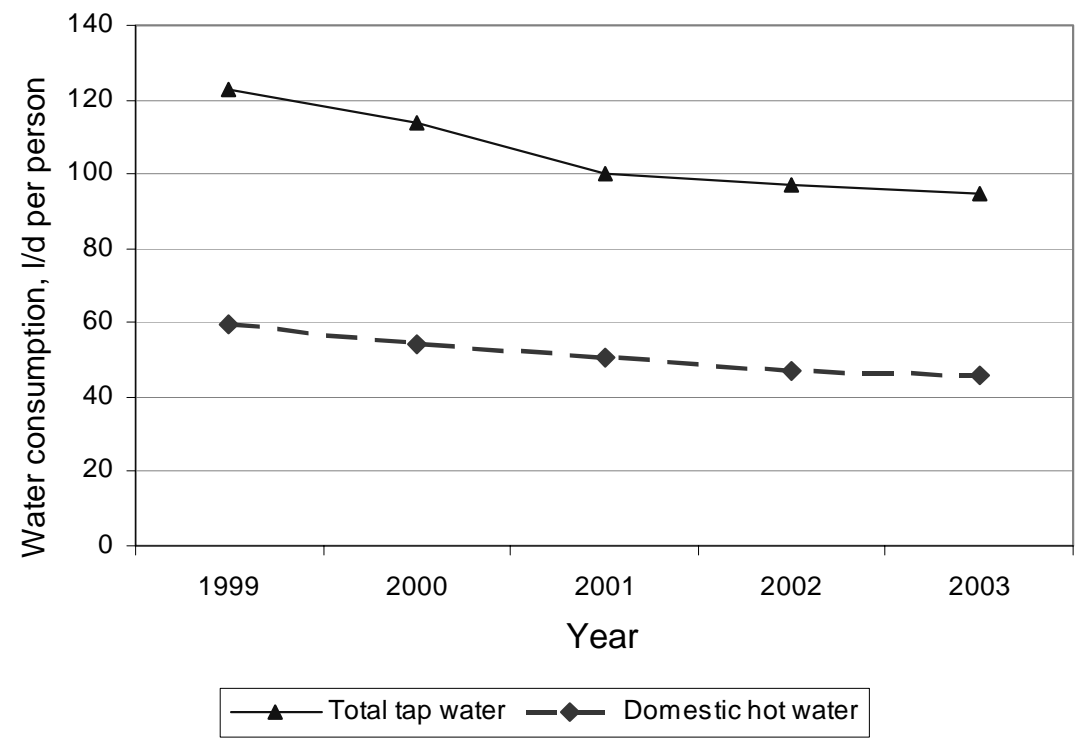

Fig. 6. Domestic hot water and total tap water consumption in 1/d per person in years 1999-2003. 
Table 3. Average heat consumption of water heating per year in 60 -apartment buildings

\begin{tabular}{c|c}
\hline Year & Heat consumption, MWh per year \\
\hline 1999 & 149 \\
2000 & 136 \\
2001 & 128 \\
2002 & 117 \\
2003 & 115
\end{tabular}

To show the dependence of hot water consumption on total water consumption, Fig. 6 gives the average total water consumption data in investigated apartment buildings for the last five years. The total water consumption from $123 \mathrm{l} / \mathrm{d}$ per person in 1999 decreased to $95 \mathrm{l} / \mathrm{d}$ per person in 2003. The latter data are close to water consumption in Belgium in 1998 and in the Czech Republic and Bulgaria in 2001 in the housing sector $\left[{ }^{1}\right]$, but comparing with those in Finland our consumption is approximately 1.5 times less.

As in the last five years decrease in domestic hot water consumption and the total water consumption was $23 \%$, we can consider the initial data of domestic hot water consumption correct (the role of local tap water heating equipment is insignificant). The share of domestic hot water in total water consumption is $46 \%$ and has been approximately the same in the last five years.

The main reasons for a decrease in domestic hot water consumption in Tallinn apartment buildings in recent years are:

- high cost of water and heat and continued tendency of the increase of the cost;

- consumption metering in apartments;

- extensive renovation of domestic hot water systems, including circulation renovation;

- use of modern equipment (taps, showers).

\section{CONCLUSIONS}

Both hot and cold water consumption in apartment buildings in Tallinn shows a clear tendency of decrease. In 2003 the hot and total water consumption was 46 and $95 \mathrm{l} / \mathrm{d}$ per person, respectively; the share of domestic hot water in total water consumption was $46 \%$. A decrease in domestic hot water consumption within the five last years has resulted in the decrease of heat consumption in apartment buildings by about $6 \%$.

The analysis of the domestic hot water consumption profile per week shows essential changes in the consumption habits of people in recent years: top consumption in the evenings has been replaced with that in the mornings and evenings. 


\section{ACKNOWLEDGEMENTS}

The authors are grateful to the AS Minu Vara for providing data about domestic hot water consumption. We would also like to thank the Ministry of Economy and Communication of Estonia for support.

\section{REFERENCES}

1. Veekasutus ja reoveekäitlus Euroopa Liidu liikmes- ja kandidaatriikides. Keskkonnatehnika, $2003,5,52-55$.

2. Kõiv, T.-A. Experimental investigation of hot tap water consumption mode in dwellings of Tallinn. Proc. Tallinn Polytechnical Institute, 1977, No. 420 (in Russian).

3. Kõiv, T.-A. Heat energy consumption in heating and hot tap water systems in apartment buildings. Proc. Estonian Acad. Sci. Eng., 1998, 4, 225-232.

4. Kõiv, T.-A. and Toode, A. Heat energy and water consumption in apartment buildings. Proc. Estonian Acad. Sci. Eng., 2001, 7, 235-241.

5. Kozin, V., Levina, V., Markov, A., Pronina, I. and Slemzin, V. Heat Supply. Vysshaya shkola, Moscow, 1980 (in Russian).

6. Ionin, A., Hlybov, B., Bratenkov, V. and Terletskaya, E. V. Heat Supply. Strojizdat, Moscow, 1982 (in Russian).

7. Gromov, N. K. Heat Substations of District Heating Networks. Energiya, Moscow, 1979 (in Russian).

8. Kinnistu veevärgi projekteerimine. EVS 835 : 2003. Eesti Standardikeskus, Tallinn, 2003.

\section{Sooja vee tarbimise uurimine kortermajades}

\section{Alvar Toode ja Teet-Andrus Kõiv}

Tallinna viies kortermajas viidi läbi sooja vee tarbimise uurimine. Ajavahemikus 1973-2003 vähenes sooja vee tarbimine üle kahe korra. On toodud sooja vee ja kogu veetarbimise keskmised näitajad kortermajades aastatel 1999-2003. Sooja vee tarbimine vähenes sellel ajavahemikul ligikaudu $20 \%$. 